\title{
PENYELESAIAN WANPRESTASI DALAM HUBUNGAN KONTRAKTUAL (STUDI KASUS PUTUSAN NO. 44/PID/2018/PT.DPS)
}

\author{
Oleh: \\ Sheanny Scolastika \\ I Nyoman Darmadha \\ Program Kekhususan Hukum Bisnis Fakultas Hukum \\ Universitas Udayana
}

\begin{abstract}
ABSTRAK
Terhadap suatu kontrak sering terjadi adanya pihak tertentu yang tidak memenuhi prestasi yang kemudian perbuatan tersebut disebut dengan wanprestasi. Semestinya terhadap perkara wanprestasi dilakukan penyelesaiannya secara hukum keperdataan, namun ternyata di dalam praktiknya terhadap pelanggaran terhadap sebuah perjanjian sering pula dilaporkan sebagai tindak penipuan dan penyelesaian secara hukum pidana. Penelitian ini menggunakan metode normatif dengan menggunakan pendekatan kasus. Adapun hasil dari penelitian ini adalah terhadap perkara ini terdapat kesalahan dan/atau kekeliruan penerapan hukum dalam judex facti pada Pengadilan Negeri Denpasar dan Pengadilan Tinggi Bali memperbaiki serta mengadili perkara tersebut dengan memberikan pertimbangan hukum yang berbeda yang menyatakan bahwa perkara tersebut merupakan perkara perdata dan memutus lepas para terdakwa. unsur "kesalahan" pada wanprestasi ditentukan dari lalainya seseorang dalam memenuhi prestasi pada hubungan kontraktual. Untuk itu agar para pihak atau masyarakat dalam melakukan suatu perjanjian perlu memahami secara jelas karakteristik pembeda antara tindak penipuan dan perbuatan wanprestasi dalam sebuah hubungan kontraktual, dan pada perkara perjanjian yang diindikasikan sebagai tindak pidana penipuan harus dibuktikan terlebih dahulu unsure maksud atau niat (mens rea) dengan sengaja melakukan penipuan bukan diakibatkan oleh kelalaian.
\end{abstract}

Kata Kunci : Wanprestasi, Delik Penipuan, Hubungan Kontraktual 


\begin{abstract}
In a contract there is often a certain party that does not fulfill the achievement, then the action is called default. The case of default must be settled in civil law, but it turns out in practice that violations of an agreement are often reported as acts of fraud and settlement under criminal law. This study uses a normative method using a case approach. The results of this study are that there are errors and / or errors in the application of the law in judex facti at the Denpasar District Court and the Bali High Court to correct and adjudicate the case by providing different legal considerations stating that the case is a civil case and disconnects the defendants. the element of "error" in default is determined by the failure of someone to fulfill an achievement in a contractual relationship. For this reason, the parties or the community in carrying out an agreement need to clearly understand the distinguishing characteristics between fraudulent acts and defaults in a contractual relationship, and in agreement cases which are indicated as fraudulent acts must be proven in advance the intention or intention (mens rea) intentionally committing fraud is not caused by negligence.
\end{abstract}

Keywords : Default, Fraud Delegation, Contractual Relations 


\section{PENDAHULUAN}

\subsection{Latar Belakang Masalah}

Kodratnya masyarakat tidak dapat hidup sendiri maka diperlukan sebuah hubungan antara manusia satu dengan lainnya, sehingga tentu terdapat suatu ikatan-ikatan yang memerlukan adanya aturan. Interaksi antar individu menimbulkan sebuah perikatan yang bersifat privat. Perikatan yang dimaksudkan adalah sebuah hubungan hukum antara dua orang atau dua pihak berdasarkan salah satu pihak berhak menuntut sesuatu hal dari pihak yang lain dan pihak yang lain berkewajiban untuk memenuhi tuntutan itu sesuai dengan perjanjian. Pengertian perjanjian sebagaimana diuraikan dalam Pasal 1313 KUHPerdata yaitu "suatu perbuatan dengan mana satu orang atau lebih mengikatkan dirinya terhadap satu orang lain atau lebih." Obyek perjanjian berupa prestasi yaitu suatu kewajiban yang harus dipenuhi dan/atau dilaksanakan oleh para pihak sesuai dengan apa yang diperjanjikan. ${ }^{1}$ Dalam sebuah perjanjian sering terjadi adanya pihak tertentu ingkar janji atau wanprestasi, tidak melaksanakan hak dan kewajiban yang sudah disepakati. Perkataan wanprestasi berasal dari bahasa Belanda, yang artinya prestasi buruk. ${ }^{2}$ Wanprestasi artinya ia tidak memenuhi kewajibannya atau terlambat memenuhinya tetapi tidak seperti yang telah diperjanjikan. ${ }^{3}$ Tidak dipenuhinya

\footnotetext{
1 FX. Suhardana. 2009, Contract Drafting Kerangka Dasar dan Teknik Penyusunan Kontrak. UniversitasAtma Jaya Yogyakarta; Yogyakarta, h.12

${ }^{2}$ Yogi Yustyawan, Gde; -, Marwanto. Akibat Hukum Wanprestasi Yang Dilakukan Oleh Pembeli Dalam Perjanjian Jual Beli Tanah Yang Belum Lunas Di Kabupaten Badung. Kertha Semaya, [S.1.], apr. 2015. Available at: $<$ https://ojs.unud.ac.id/index.php/kerthasemaya/article/view/13168>. Date accessed: 28 mar. 2019.

3 Subekti, 2007, Kitab Undang-Undang Hukum Perdata, PT. Arga Printing, Jakarta, h.146
} 
kewajiban oleh debitur disebabkan oleh dua kemungkinan alasan, yaitu:

a. Karena kesalahan debitur, baik dengan sengaja tidak dipenuhi kewajiban maupun karena kelalaian.

b. Karena keadaan memaksa (overmacht), force majeure, jadi di luar kemampuan debitur. ${ }^{4}$

Bahwa bilamana terjadi konflik yang didasarkan pada perjanjian-perjanjian tersebut, maka semestinya dilakukan penyelesaiannya melalui sebuah peradilan perdata, namun ternyata didalam praktiknya terhadap pelanggaran terhadap sebuah perjanjian sering pula dilakukan dengan cara pidana yakni dengan melaporkan kepada pihak Kepolisian dan kemudian diputus sebagai perkara pidana penipuan seperti pada Putusan Pengadilan Negeri Denpasar Nomor 601/Pid.B/2018/PN.Dps yang kemudian dibatalkan dengan Putusan Pengadilan Tinggi Nomor 44/Pid/2018/PT.Dps. Kata penipuan identik dengan hukum pidana, sedangkan wanprestasi masuk ke wilayah hukum perdata. ${ }^{5}$ Hal ini lah yang menimbulkan penafsiran berbeda (ambigu) terhadap penyelesaian perkara yang didasarkan pada suatu perjanjian atau perikatan.

Sesuai dengan latar belakang yang telah dijelaskan maka diperlukan sebuah penelitian, sehingga penulis dalam jurnal ini mengangkat judul : "PENYELESAIAN WANPRESTASI DALAM HUBUNGAN KONTRAKTUAL (STUDI KASUS PUTUSAN NO. 44/PID/2018/PT.DPS)"

\footnotetext{
${ }^{4}$ Abdulkadir Muhammad, 2000, Hukum Perdata Indonesia, PT Citra Aditya, Bandung, (selanjutnya disingkat Abdulkadir Muhammad I) h. 203

${ }^{5}$ Juliawan Saputra, I Ketut Gde; Sri Utari, Anak Agung. Perbedaan Wanprestasi Dengan Penipuan Dalam Perjanjian Hutang Piutang. Kertha Wicara, [S.1.], sep. 2015. Available at:

<https://ojs.unud.ac.id/index.php/kerthawicara/article/view/15363>. Date accessed: 28 mar. 2019.
} 


\subsection{Permasalahan}

1.2.1. Bagaimanakah akibat hukum terhadap debitur yang wanprestasi diindikasikan sebagai tindak pidana penipuan berdasarkan Putusan Pengadilan Tinggi No. 44/Pid/2018/PT.Dps ?

1.2.2. Bagaimanakah pertimbangan hakim dalam memutus perkara perdata terhadap debitur yang diindikasikan sebagai tindak pidana penipuan yang berkaitan dengan adanya wanprestasi pada hubungan kontraktual ?

\subsection{Tujuan Penelitian}

Penulisan penelitian ini bertujuan menganalisis penyelesaian wanprestasi dalam hubungan kontraktual melalui studi kasus dalam perkara nomor No. 44/PID/2018/PT.Dps.

\section{ISI MAKALAH}

\subsection{Metode Penelitian}

Skripsi ini disusun menggunakan penelitian hukum normatif. Penelitian hukum normatif adalah penelitian hukum yang meletakkan hukum sebagai sebuah bangunan sistem norma. ${ }^{6}$ Pada penelitian ini, peneliti memfokuskan penelitian pada analisis mengenai pertimbangan dan petitum putusan hakim di tingkat pertama dan banding sehubungan dengan ganti kerugian yang diakibatkan wanprestasi pada perjanjian utang piutang dalam Putusan No. 44/PID/2018/PT.DPS, dimana pembahasannya akan meneliti produk hukum berupa peraturanperaturan yang terkait dengan perjanjian secara umum dan peraturan-peraturan yang terkait dengan ganti kerugian, serta pula doktrin-doktrin dari ahli hukum perdata. Dengan demikian,

\footnotetext{
${ }^{6}$ Mukti Fajar dan Yulianto Ahmad, 2010, Dualisme Penelitian Hukum Normatif dan Empiris, Pustaka Pelajar,Yogyakarta, h.34.
} 
adalah sesuai apabila penelitian ini digolongkan sebagai penelitian hukum yuridis normatif.

\section{a. Jenis Pendekatan}

Sedangkan pendekatan penelitian yang dilakukan peneliti yaitu pendekatan kasus (case approach). Pendekatan kasus dapat digunakan oleh peneliti jika permasalahan terdapat kekaburan norma dalam penerapannya oleh hakim dalam memutus perkara. Dari segi norma bahwa normanya sudah jelas tetapi kurang tepat diterapkan oleh hakim. ${ }^{7}$

\section{b. Bahan Hukum}

Bahan hukum primer adalah bahan hukum yang bertautan dengan permasalahan yang akan diteliti, meliputi:

a. KUHPerdata

b. KUHPidana

c. KUHAP

d. Putusan Pengadilan Tinggi Bali Nomor 44/Pid/2018/PT.Dps

Bahan hukum sekunder, memberikan penjelasan tentang bahan hukum primer, yaitu:

a. Buku-buku tentang Hukum Perikatan di Indonesia.

b. Buku-buku tentang Wanprestasi di Indonesia.

c. Berbagai jurnal, makalah, surat kabar, dan artikel yang berkaitan dengan permasalahan dalam penelitian. 8

Bahan hukum tersier, yaitu bahan penelitian yang menjelaskan terkait bahan hukum primer dan bahan hukum sekunder, seperti kamus hukum, ensiklopedia maupun bahan lain yang sesuai dengan permasalahan dalam penelitian.

\section{c. Teknik Pengumpulan Data}

${ }^{7}$ Pasek Diantha, 2017, Metodelogi Penelitian Hukum Normative Dalam Justifikasi Teori Hukum, Kencana, Jakarta, h. 165

${ }^{8}$ Mukti Fajar dan Yulianto Achmad, Op. Cit., h. 222 
Penelitian ini menggunakan studi dokumen berupa dokumen meliputi salinan putusan, prosedur berperkara dan dokumen lainnya.

\section{d. Teknik Analisis}

Bahan hukum yang diperoleh kemudian dianalisa menggunakan analisis deskriptif kualitatif. Bahan hukum yang didapat selanjutnya dilakukan pembahasan, pemeriksaan kemudia diolah menjadi data informasi.

\subsection{Hasil dan Analisis}

\subsubsection{AKIBAT HUKUM TERHADAP DEBITUR YANG WANPRESTASI DIINDIKASIKAN MELAKUKAN TINDAK PIDANA PENIPUAN BERDASARKAN PUTUSAN PENGADILAN TINGGI BALI NO. 44/PID/2018/PT.DPS}

Terhadap perkara wanprestasi yang diindikasikan sebagai tindak pidana penipuan seperti pada Putusan Pengadilan Negeri Denpasar Nomor 601/Pid.B/2018/PN.Dps, kemudian dalam Putusan Pengadilan Tinggi Bali Nomor 44/Pid/2018/PT.Dps putusan tersebut dibatalkan dan diberikan putusan lepas (onslag van recht vervolging). Menurut Lilik Mulyadi ${ }^{9}$, bahwa putusan lepas (onslag van recht vervolging) adalah segala tuntutan hukum atas perbuatan yang dilakukan terdakwa dalam surat dakwaan jaksa atau penuntut umum telah terbukti secara sah dan meyakinkan menurut hukum, akan tetapi terdakwa tidak dapat dijatuhi pidana, karena perbuatan tersebut bukanlah tindak pidana, misalnya merupakan bidang hukum perdata atau hukum dagang. Sesuai dengan perkara dalam putusan No. 44/PID/2018/PT.Dps yang menjadi dasar atau sumber timbulnya hak dan kewajiban masing-masing pihak yang terikat dalam

\footnotetext{
${ }^{9}$ Lilik Mulyadi, 2007, Hukum Acara Pidana, PT Citra Aditya Bakti , Bandung, h. 153
} 
sebuah Memory of Agreement adalah sebuah perjanjian dalam ranah hukum perdata maka terhadap tuntutan pihak yang merasa dirugikan terhadap tidak dipenuhinya isi perjanjian tersebut haruslah melalui suatu gugatan wanprestasi dalam jalur hukum keperdataan bukanlah melalui jalur hukum pidana. Adapun akibat hukum lainnya bagi debitur yang melakukan wanprestasi atau yang telah dinyatakan lalai adalah :

1. Debitur diwajibkan membayar ganti rugi, ketentuan ini berlaku untuk semua perikatan.

Sesuai dengan pasal 1243 dalam hal penggantian rugi terhadap debitur yang wanprestasi, undang-undang masih memberikan perlindungan dengan pemberian batasan-batasan dalam hal penggantian rugi sebagaimana seharusnya dibayar oleh debitur atas penuntutan dari kreditur. Dapat kita lihat pembatasan tersebut pada Pasal 1247 dan 1248 KUHPer.

2. Pembatalan Perjanjian

Dalam hal ini sebagai sanksi atas kelalaian yang ditimbulkan debitur maka ditujukan agar kedua belah pihak berada pada keadaan sebelum diadakannya perjanjian. Oleh sebab itu apabila salah satu pihak telah menerima sesuatu dari pihak lain baik uang atau barang maka hal tersebut harus dikembalikan sesuai dengan Pasal 1266 KUHPer.

3. Peralihan Resiko

Ketentuan ini hanya berlaku bagi perikatan untuk memberikan sesuatu sesuai dengan pasal 1237 KUHPer.

4. Membayar biaya perkara apabila diperkarakan di muka pengadilan. 
Dalam kasus ini debitur tidak dapat dijatuhi pidana karena unsur-unsur tindak pidana tidak terpenuhi oleh karena hubungan hukum antara debitur dan kreditur adalah murni kontraktual. Debitur diwajibkan ganti rugi sesuai dengan pasal 1243 KUHPer dan membayar biaya perkara di muka pengadilan.

\subsubsection{ANALISIS TERHADAP PERTIMBANGAN HAKIM DALAM PUTUSAN PENGADILAN TINGGI BALI NOMOR 44/PID/2018/PT.DPS}

Dalam perkara ini yang perlu kita cermati berkaitan dengan Putusan Pengadilan Tinggi adalah dengan membatalkan judex facti putusan Pengadilan Negeri Denpasar, dalam putusan Hakim Pengadilan Negeri Denpasar para terdakwa dinyatakan terbukti melakukan tindak pidana 'penipuan' dan menjatuhkan sanksi pidana penjara terhadap Terdakwa I yaitu selama 2 (dua) tahun dan Terdakwa II selama 1 (satu) tahun 9 (sembilan) bulan. Majelis hakim judex facti pada pengadilan Negeri Denpasar mengeyampingkan unsur-unsur adanya hubungan kontraktual antara para pihak dan memandang perkara ini merupakan tindak pidana 'penipuan' karena fokus pembuktiannya lebih mengarah pada unsur-unsur dalam Pasal 378 KUHP seperti :

1. Barang siapa

2. Dengan maksud hendak menguntungkan diri sendiri atau orang lain dengan melawan hukum

3. Baik dengan memakai nama palsu atau martabat palsu, baik dengan akal dan tipu muslihat, maupun dengan rangkaian perktaan-perkataan bohong, membujuk orang supaya memberikan sesuatu barang, membuat utang atau menghapuskan piutang. 
Lebih lanjut Majelis Hakim Pengadilan Tinggi Bali lebih mencermati hubungan hukum yang terjadi antara para terdakwa dan saksi II merupakan hubungan hukum yang diawali dengan suatu kesepakatan berupa Memorandum of Agreement/Nota Kesepakatan tertanggal 26 Mei 2014. Para terdakwa tidak dapat memenuhi isi dari MOA tersebut dan terdapat pihak yang merasa dirugikan. Maka dalam perkara ini Hakim Pengadilan Tinggi tidak sependapat dengan Hakim Pengadilan Negeri dan memutuskan melepaskan para terdakwa oleh karena tidak terpenuhi unsurunsur tindak pidana sehingga terdakwa dibebaskan dari segala tuntutan hukum (Onslag van rech vervolging).

Fenomena putusan hakim dalam perkara ini sesungguhnya membuktikan bahwa belum terdapat kesamaan pemahaman dan penafsiran berkaitan dengan soal konsep 'wanprestasi' dan 'penipuan'. Dengan kata lain belum terdapat pedoman yang baku yang dapat dijadikan acuan mengenai batasan antara perbuatan wanprestasi dan penipuan yang sama-sama didahului atau diawali oleh hubungan hukum perjanjian atau kontraktual.

Dengan demikian, dalam perkara ini putusan Pengadilan Tinggi lebih melihat pada fakta hukum di persidangan, bahwa tidak terpenuhinya sebagian isi perjanjian yang dibuat antara para terdakwa dan saksi II bukan merupakan suatu 'kesengajaan yang dituju' ( unsur 'dengan maksud' dalam delik penipuan) melainkan lebih mengarah pada suatu perbuatan 'ingkar janji' atau 'wanprestasi'. Perbuatan para terdakwa 'bukan merupakan suatu tindak pidana' melainkan merupakan 'perbuatan ingkar janji atau wanprestasi' yang berada dalam ruang lingkup hukum Keperdataan. Dan pada hal ini tidak ada niat dari para Terdakwa untuk menipu, melainkan merupakan tidak dapat memenuhi prestasi, sehingga upaya yang dilakukan oleh pihak yang 
dirugikan yaitu dengan mengajukan gugatan perdata atas dasar 'wanprestasi' untuk pemenuhan prestasi, atau ganti rugi dan pembatalan kontrak.

\section{PENUTUP}

\section{Kesimpulan}

Berdasarkan hasil pembahasan penelitian dalam skripsi ini, maka dapat diambil kesimpulan sebagai berikut:

1. Dengan tidak terpenuhinya unsure-unsur tindak pidana, maka akibat hukum terhadap perkara wanprestasi yang diindikasikan sebagai tindak pidana penipuan adalah diputus lepas (Onslag van rech vervolging). Berdasarkan perkara ini maka akibat hukum terhadap debitur sesuai dengan pasal 1234 KUHPer adalah debitur diwajibkan ganti rugi dan membayar biaya perkara di muka pengadilan.

2. Terhadap perkara ini terdapat kesalahan dan/atau kekeliruan penerapan hukum dalam judex facti pada Pengadilan Negeri Denpasar dan Pengadilan Tinggi Bali memperbaiki serta mengadili perkara tersebut dengan memberikan pertimbangan hukum yang berbeda yang menyatakan bahwa perkara tersebut merupakan perkara perdata dan memutus lepas para terdakwa. 


\section{DAFTAR PUSTAKA}

Abdulkadir Muhammad, 2000, Hukum Perdata Indonesia, PT Citra Aditya, Bandung

Agus Yudha Hernoko, 2011, Hukum Perjanjian, Asas Proposionalitas Dalam Kontrak Komersil, Kencana, Jakarta

FX. Suhardana. 2009, Contract Drafting Kerangka Dasar dan Teknik Penyusunan Kontrak, Universitas Atma Jaya Yogyakarta, Yogyakarta

M. Yahya Harahap, 1986, Segi-Segi Hukum perjanjian, Alumni, Bandung

Subekti, 2007, Kitab Undang-Undang Hukum Perdata, PT. Arga Printing, Jakarta

Yahman, 2014, Karakteristik Wanprestasi dan Tindak Pidana Penipuan, Prenamedia Group, Jakarta

Pasek Diantha, 2017, Metodelogi Penelitian Hukum Normative Dalam Justifikasi Teori Hukum, Kencana, Jakarta

\section{JURNAL}

Juliawan Saputra, I Ketut Gde; Sri Utari, Anak Agung. Perbedaan Wanprestasi Dengan Penipuan Dalam Perjanjian Hutang Piutang. Kertha Wicara, [S.1.], sep. 2015. Available at: $<$ https://ojs.unud.ac.id/index.php/kerthawicara/article/vi ew/15363>. Date accessed: 28 mar. 2019.

Yogi Yustyawan, Gde; -, Marwanto. Akibat Hukum Wanprestasi Yang Dilakukan Oleh Pembeli Dalam Perjanjian Jual Beli Tanah Yang Belum Lunas Di Kabupaten Badung. Kertha Semaya, [S.1.], apr. 2015. Available at: $<$ https://ojs.unud.ac.id/index.php/kerthasemaya/article/v iew/13168>. Date accessed: 28 mar. 2019.

\section{PERATURAN PERUNDANG-UNDANGAN}

Subekti, R, dan R. Tjitrosudibio, 2003, Kitab Undang-undang Hukum Perdata (KUH Perdata), Pradnya Paramita, Jakarta

Moeljatno, 2005, Kitab Undang-undang Hukum Pidana (KUHP) ,Cet- 24 , Bumi Aksara, Jakarta

Undang-Undang Nomor 8 Tahun 1981 tentang Hukum Acara Pidana 